REPRODUCTION

\title{
The human embryo in the Christian tradition: a reconsideration
}

D A Jones

J Med Ethics 2005;31:710-714. doi: 10.1136/jme.2004.011593

Recent claims that the Christian tradition justifies destructive research on human embryos have drawn upon an article by the late Professor Gordon Dunstan which appeared in this journal in 1984. Despite its undoubted influence, this article was flawed and seriously misrepresented the tradition of Christian reflection on the moral status of the human embryo.

1 n January 2001, the Anglican Bishop of Oxford claimed that destructive embryo research was consistent with traditional Christian thinking on the moral status of the embryo:

I should like to suggest that it was only in the 19th century that the [Roman Catholic] position became firmed up. Earlier Christian thought on this subject indicates an awareness of a developing reality, with developing rights as we would put it.'

The bishop was subsequently appointed chair of the House of Lords Select Committee on Stem Cell Research, which conducted the most significant parliamentary review of embryo experimentation since the Warnock committee, which reported in 1984 .

The bishop's argument was based on an article by Professor Gordon Dunstan. This article was written as a submission to the Warnock committee and was published in 1984 in this journal. ${ }^{2}$ Dunstan asserted:

The claim to absolute protection for the human embryo "from the beginning" is a novelty in the Western, Christian and specifically Roman Catholic moral traditions. It is virtually a creation of the later nineteenth century, a little over a century ago; and that is a novelty indeed as traditions go (Dunstan, ${ }^{2}$ p 38).

Correspondence to: D A Jones, St Mary's College, Waldegrave Road, Strawberry Hill Twickenham, TWI 4SX UK; jonesd@smuc.ac.uk

Received

20 December 2004

In revised form

10 March 2005

Accepted for publication

14 March 2005

....................... reiterated in $1988 .{ }^{5}$ This paper will argue that Dunstan's article is flawed and misleading. The criticisms of the present paper apply equally to both versions

\section{THE "CATENA OF EVIDENCES"}

Dunstan draws on a range of sources spanning three thousand years of moral reflection (Dunstan, ${ }^{2}$ p 39). These include two greatly respected works of Catholic scholarship ${ }^{67}$; five ancient near eastern law codes, namely Babylonian, Assyrian, Hittite, and the Hebrew and Greek versions of Exodus 21:22; two ancient embryologists, Hippocrates and Aristotle; four representatives of the early church, Tertullian, Basil the Great, Gregory of Nyssa, and Augustine of Hippo; three Celtic penitentials, the Bigotian, Hibernian, and Old Irish'; three English lawyers, Henry of Bracton, Blackstone, and Coke; one Tudor physician, Thomas Vicary; the greatest of all mediaeval poets, Dante Aligheri; five Catholic moral theologians, Raymond de Penafort, Thomas Aquinas, Cornelius a Lapide, John de Lugo, Alphonsus Liguori, and Aertynus, and no fewer than five popes, Innocent III, Sixtus V, Gregory XIV, Pius IX, and Leo XIII.

These writers are said to reflect a single coherent moral tradition that "attempted to grade the protection accorded to the nascent human being according to the stages of its development". The article presents Pius IX as the one who effectively abandoned the tradition when, in 1869, he extended the penalty of excommunication to all abortions "without distinction... as to the gestational age of the fetus".

Dunstan acknowledges three "apparent dissentients" to the tradition he claimed was dominant: Tertullian, who is discounted with relative ease as he was "by no means accounted orthodox"; Basil the Great, whose weight is counterbalanced by that of his own brother, Gregory of Nyssa, and Pope Sixtus V who in 1588 "summarily abolished the tradition" only for it to be reaffirmed in 1591 by "the next pope, Pius IX" (Dunstan, ${ }^{2}$ p 42). The date is correct but it was neither "the next pope" nor "Pius IX" but Gregory XIV, the next but one pope (after Urban VII). Having considered these three alleged exceptions, Dunstan confidently claims that the tradition according the embryo the moral status of a human being from the beginning of its development is "virtually a creation of the later nineteenth century".

At first glance, Dunstan appears to have produced a persuasive case that the Christian tradition has only relatively recently accorded absolute respect to the early embryo. His case is, 
however, much weaker than it first appears. Dunstan omits important authorities, relies on flawed sources, and fails to distinguish between divergent categories.

\section{TROUBLING OMISSIONS}

Professor Dunstan describes Tertullian as a "dissentient" for his view that "to deny birth is to hasten homicide" (Dunstan, ${ }^{2}$ p 39) but he omits to cite any other figure from the first three centuries of Christianity to show that Tertullian's view was unorthodox. In fact, the first generations of Christians, as represented by The Didache, The letter of Barnabas, Athenagoras and Municius Felix, universally characterised abortion as homicide. ${ }^{9}$ Their extension of care to the youngest and weakest was in conscious opposition to the prevalent pagan acceptance of abortion and infanticide. ${ }^{10}$ Far from adopting a "graded" view, all witnesses to the early Christian tradition reject abortion without distinction as to stage of development of the embryo.

Basil the Great is also described as a "dissentient", but again Dunstan omits consideration of the particular tradition to which he belongs. Basil was the first Christian canonist to consider a distinction between the "formed" and the "unformed" embryo and, as Dunstan acknowledges, Basil decisively rejected it. In this he was wholly in conformity with the dominant tradition of church legislation in the first millennium (Elvira (305); Ancyra (314); Basil (375); Lerida (524); Braga (527); Trullo (692); Mainz (847)), which treated abortion as homicide without distinction as to the stage of development of the embryo. ${ }^{11}$

The article contrasts Basil's view with that of his brother, Gregory of Nyssa, who once asserted that it is "not... possible to style the unformed embryo a human being, but only a potential one" (Dunstan, ${ }^{2}$ p 40). This quotation does not, however, refer to a gradation within pregnancy between the formed and unformed embryo but to a distinction between the born and the unborn child. It is from a highly polemical work in which Gregory's characterisation of the unborn is distorted by his desire to criticise the unorthodox beliefs of some Christians in Macedonia. He denied that these Christians were properly baptised and derided them as unformed and "unborn". Nevertheless, when Gregory addressed the subject directly, he argued that the unborn child possesses a spiritual soul from conception. ${ }^{12}$ Far from contradicting Basil's view, Gregory's account of ensoulment strengthens the case for treating abortion as homicide irrespective of the embryo's stage of development.

Professor Dunstan confesses that he "has not pursued the question" as to whether Basil's judgment persisted in the Greek churches. This is a rather glaring omission. In fact the Eastern churches never embraced the "graded" view that Dunstan presents as the Christian tradition until the nineteenth century.

Dunstan presents Pius IX in 1869 as breaking with received Christian tradition in a desperate attempt to oppose an alleged increase in abortion in the nineteenth century. What is omitted from this picture, among other things, is the revival in the West of the early Christian belief that the spiritual soul is infused at conception. In the sixteenth century both Calvin and Luther came to believe that the soul is present in the embryo from conception. ${ }^{13}$ In 1621 this belief was advocated within the Catholic tradition by Paolo Zacchia, who was later appointed physician to Innocent X (Jones, ${ }^{11}$ pp 163-4). The view that the soul is present from conception seemed to find further support in a series of scientific discoveries. In 1672 egg follicles were observed under the microscope. In 1677 spermatozoa were observed in the semen. Biologists in the modern era understand the development of the embryo as a continuous process with fertilisation-the fusion of egg and sperm-marking the beginning of a new living being. Dunstan fails to register these relevant advances in biological understanding and, significantly, he cites no medical authors between 1577 and the present.

What Professor Dunstan represents as a "novelty" actually represents the earliest Christian tradition as maintained by the churches of the East and as revived in the West during the Reformation. The re-emergence of the early Christian view within the Roman Catholic tradition was the result of the demise of ancient Greek biology in the wake of scientific discoveries in the seventeenth century. The belief that the early embryo deserves the protection due to a human being can hardly, therefore, be dismissed as "virtually an invention of the late nineteenth century".

\section{FLAWED AUTHORITIES}

As well as omitting significant portions of the tradition, Dunstan's case is also flawed in that the authors he quotes with approval relied heavily upon ideas and authorities that are no longer credible. For example, Dunstan emphasises the importance of a passage in one particular Greek translation of the Bible (the "Septuagint" translation) which introduced the formed/unformed distinction into the Christian tradition:

\section{And if two men are fighting and strike a pregnant woman and her infant departs not fully formed, he shall be forced to pay a fine: according to whatever the woman's husband shall lay upon him, he shall give with what is fitting. But if it is fully formed, he shall give life for life (Exodus 21:22-23 from the Septuagint translation) (Dunstan, ${ }^{2} \mathrm{p}$ 43).}

Dunstan admits, however, that this translation marks a "significant departure" from the original Hebrew of the passage. The original Hebrew text contains no reference to formed or unformed, but distinguishes penalties according to whether the departure of the infant from the womb results in "serious harm". The Septuagint version of this passage is thus a mistranslation, shaped not by the underlying Hebrew but by what Dunstan acknowledges is "an outmoded" Greek embryology (Dunstan, ${ }^{2}$ p 43 ).

This unfortunate mistranslation had an extensive influence on later writers. Dunstan quotes a passage from Augustine to the effect that killing an unformed embryo is not homicide:

If what is brought forth is unformed but at this stage some sort of living, shapeless thing, then the law of homicide would not apply, for it could not be said that there was a living soul in that body, for it lacks sense, if it be such as is not yet formed and therefore not yet endowed with sense (Dunstan, ${ }^{2} \mathrm{p}$ 40).

Nevertheless, Augustine's attitude is more ambiguous than it might seem and this becomes evident if we examine this passage more closely. This is made difficult because, unaccountably and without warning the reader, Dunstan has deleted a whole line from the middle of the passage. After "living, shapeless thing" Augustine adds the qualification "since the great question of the soul is not to be rushed into rashly with a thoughtless opinion". This raises the issue of the origin of the soul, a question which Augustine discusses in many of his writings. Augustine remained open to the view that the soul was generated by the parents, as this seemed to explain the inheritance of original sin. This view implies that the soul is present from conception. By deleting the line Dunstan conceals the fact that Augustine's account of the origin of soul is in tension with the rest of this passage. Indeed, earlier in the article Dunstan explicitly acknowledges 
that the view that the soul is given by the parents, as Tertullian held, "add[s] importance to the early embryo" (Dunstan, ${ }^{2}$ p 40).

If Augustine is keen to resist the "rash" or "thoughtless" rejection of the presence of the soul in the early embryo, why does he state that abortion of an unformed embryo is not homicide? He says this because he is constrained by a translation of scripture which applies the punishment "life for life" only for abortion of a formed infant. Seeking some way of resolving this tension, Augustine suggests that, while the soul may be present in the unformed embryo, it would not yet be a "living soul" (anima viva) because it would not be endowed with sense. This explanation is hardly satisfying. If there is a soul in the unformed embryo then, even if it is dormant, it is surely alive. Augustine struggles and fails to make sense of a text that we now know to be a mistranslation. Apart from commenting on this one text he never suggested that the embryo was less than fully human. In particular, he continued to think that the soul might be generated by the parents and, thus, might be present in the embryo from conception. ${ }^{14} 1516$

In the thirteenth century, the doctrine of "delayed ensoulment" became prevalent among Western Christians not only because of the Septuagint but also through the direct influence of the biological works of Aristotle. Aristotle stated that the body was formed at forty days after conception for males and at ninety days for females. ${ }^{17}$ Many Christians inferred that ensoulment happened at this point. One prominent example is Thomas Aquinas. Dunstan provides six quotations in which Aquinas affirms delayed ensoulment, of which three explicitly mention Aristotle. These references inevitably raise the question whether Aquinas's conclusions were reliant upon Aristotle's biology, and, if so, what weight can be given to them in a modern context. For example, Aquinas took from Aristotle the belief that the embryo was shaped by the power of the male parent acting through vital spirits in the seed.

The formation of the body is caused by the generative power, not of that which is generated [the embryo], but of the father generating from seed. ${ }^{18}$

For Aquinas, the power of something follows from its nature. If the power to develop into a man were inherent in the embryo then it would already possess a human nature. In the light of modern genetics, however, it is undeniable that the power of development is inherent in the embryo. The embryo is shaped, not by the father acting at a distance, but by the embryo's own genetic nature. Thus, if we apply Aquinas's principles to modern biology, it seems that the embryo must possess a human nature, and hence a human soul, from fertilisation.

The "graded" view that Dunstan finds in Augustine and Aquinas can be traced directly to the regrettable influence of a mistranslation of scripture and to an erroneous ancient biology. Where significant thinkers from the past such as these relied on mistaken authorities we cannot give much credence to their particular conclusions. We can, however, still profit by considering their general method and approach in combining the best available scientific knowledge with enduring philosophical and ethical principles. It is noteworthy that, even though they were influenced by the Septuagint and by Aristotle's biology, other elements in the thought of Augustine and Aquinas suggest that the embryo possesses a spiritual soul from conception. ${ }^{14-16} 1920$

\section{CONFUSED DISTINCTIONS}

A final flaw in Dunstan's article is that it confuses different theological, legal and moral categories and, on the basis of this, supposes that various writers would support actions which in fact they explicitly rejected. For example, Dunstan cites an important legal decision of Innocent III which introduced the ensouled/not ensouled distinction into Western canon law. It is important to note, however, that this decision was narrowly concerned with the technical question of irregularity: whether a monk whose actions inadvertently caused a miscarriage should be barred from becoming a cleric. With respect to penance, early abortion was regarded as homicide. This is made clear in a passage of Raymond de Penafort quoted in the article.

If however [the embryo] is not ensouled, [abortion] is not said to be homicide so far as concerns irregularity, but it is accounted homicide in regard to penance [emphasis added] (Dunstan, ${ }^{2}$ p 40).

Penance is the expression of sorrow for sin, and the level of penance expresses the moral seriousness of the sin. Thus, in the middle ages, causing abortion was morally equated with homicide whatever the stage of development of the embryo. Mediaeval Christians who believed that the unformed embryo was not yet a human being did not accord it the status of an irrational animal. They saw the early embryo as an already living creature whom God was preparing to receive a spiritual soul. This approach is evident-for example, in the writings of Bonaventure (d 1274), who stated that destroying an embryo before ensoulment constitutes homicide, not according to the definition of homicide (ratione homicidii) but according to the malice of homicide (maleficii). This Commentary on the Sentences 4.31.4, by Bonaventure, is quoted by Delmaille in the Dictionnaire de droit canonique ( $\mathrm{Naz}^{7} \mathrm{p}$ 1536). Since the seventeenth century Catholic theologians have increasingly come to think that the soul is present from the beginning of development. Interestingly, however, even the most recent official teaching has shied away from defining this as a matter of doctrine. Rather, what has been emphasised throughout Christian history is that the embryo should be treated as a person..$^{21}$

Dunstan asserts that in 1588, Pope Sixtus V "summarily abolished the tradition which attached culpability to the development of the fetus". As noted above, however, the tradition prior to this point did not invoke the stage of development of the embryo to determine the penance for abortion and hence its moral culpability. It was Pope Gregory XIV in 1591 who introduced the relative novelty of using ensoulment to determine canonical penance on abortion, though he still maintained that abortion before this point was a grave sin. When the law was amended by Pius IX in 1869, it was in fact brought closer to what it had been in the time of Raymond of Penafort.

It is essential to note that none of the canon legal changes of the last thousand years invoked the stage of development to determine whether the embryo should be protected. Deliberate and direct destruction of the embryo was always viewed as a grave offence. Thus those elements from the tradition identified by Dunstan, which support taking embryo destruction as a less serious crime than homicide nevertheless give no precedent for the approval, sanctioning or actively facilitating of embryo destruction. As licensing destructive research on human embryos for the sake of medical progress involves just such positive approval it cannot be justified, or at least not on the basis of the Christian tradition.

In summary:

- The earliest Christian witnesses and the churches of the east generally regard the destruction of the human embryo as homicide. 
- Belief in "delayed ensoulment" among mediaeval Western Christians was founded on a mistranslation of scripture and on an outmoded embryology.

- Even when the doctrine of delayed ensoulment was believed, Christians continued to extend moral and legal protection to the human embryo from the beginning.

All the authorities cited by Professor Dunstan in favour of embryo research in fact regarded the deliberate destruction of the early embryo as homicide or as something at least analogous to homicide. None sanctioned the intentional destruction of unborn lives at any stage of development. Dunstan's thesis that the Christian tradition lends support to destructive research on early human embryos simply turns history on its head! While it is regrettable that this fallacy has been uncritically restated by the Bishop of Oxford and by the Primate of Australia, it is encouraging to see it squarely contradicted by the Archbishop of Canterbury, among others: my article, "A theologian's brief", was written as a submission to the House of Lords Select Committee on Stem Cell Research and was endorsed by a number of theologians, including Rowan Williams, at that time Bishop of Monmouth. ${ }^{22}$

\section{REFERENCES}

1 House of Commons official report (Hansard) 2001 January 22; 621: cols 357, (No 16.).

2 Dunstan GR. The moral status of the human embryo: a tradition recalled. J Med Ethics 1984; 1:38-44.

3 Carnley P. Such is life. The Bulletin, 2002 Apr 16, 36-8.

4 www.isscr.org/scientists/ethics.htm (accessed 15 Jun 2005).
5 Dunstan GR. The human embryo in the Western moral tradition. In: Dunstan GR, Sellars MJ, eds. The status of the human embryo. London: King Edwards Hospital Fund, 1988:50.

6 Vacant A, Mangenot E, eds. Dictionnaire de theologie catholique. Paris: Larouzey et Ane, 1903.

7 Naz R, ed. Dictionnaire de droit canonique. Paris: Larouzey et Ane, 1938.

8 Bieler I. The Irish penitentials. Dublin: Institute for Advanced Studies, 1963.

9 Gorman MJ. Abortion and the early church: Christian, Jewish and pagan attitudes in the GrecoRoman world. New York: Paulist Press, 1982:47-62.

10 Carrick P. Medical ethics in the ancient world. Washington DC: Georgetown University Press, 2001:117-46.

11 Jones DA. The soul of the embryo. London: Continuum, 2004:62-5.

12 Gregory of Nyssa. On the making of man. In: Wilson, HA, eds. A select library of Nicene and postNicene fathers of the Christian church, series 1 vol 5. Edinburgh: T \& T Clark, 1980:29.6.

13 Williams GH. Religious residues and presuppositions in the American debate on abortion Theol Stud 1970;31:10-75.

14 Augustine. On free choice of the will [trans Williams T]. Indianapolis, IN Hackett Pub Co Inc, 1993:3.20

15 Augustine. Letter 143. In: Schaff P, ed. A select library of Nicene and postNicene fathers of the Christian church, series 1 vol 1. Edinburgh: T \& T Clark, 1980

16 Augustine. On the soul and its origin. A select library of Nicene and postNicene fathers of the Christian church, series 1 vol 5. Edinburgh: T \& T Clark, 1980

17 Aristotle. History of animals books vii-x. In: Balm DM, ed. Aristotle vol xi. London: Loeb Classical Library, 1991, 7.3, 583b, 3-23.

18 Summa theologiae [trans the fathers of the English Dominican Province, Allen, Texas]. Allen, TX: Resources for Christian Living, 1980, Illa, Q33, art 1, ad 4. 19 Heaney S. Aquinas and the presence of the human rational soul in the early embryo. Thomist 1992:56:19-48.

20 Haldane J, Lee P. Aquinas, the embryo and the ethics of abortion. Philosophy 2003;78:255-78

21 Congregation for the Doctrine of the Faith. Donum vitae. Rome: Congregation for the Doctrine of the Faith, 1987:I.1.

22 Jones DA. A theologian's brief: on the place of the human embryo within the Christian tradition and the theological principles for evaluating its moral status. Ethics Med 2001;17:143-53. that nobody before the discovery of DNA could give an adequate biological account of human generation and the point that the Bible does not actually discuss the precise point when the embryo achieves the full moral status of a human person (let alone when it might be said to have a soul that survives death).

In fact, Dr Jones's paper does not even discount the opening quotation from the Bishop of Oxford. On Dr Jones's own account, there was a "re-emergence of the early Christian view within the Roman Catholic tradition". Also, in earlier Christian thought (notably Aquinas and, on one occasion at least, Augustine) there was "an awareness of a developing reality". Where he differs from the Bishop of Oxford is in his assumption that this "re-emergence" was the authentic tradition and that its opposite, based upon a developing reality, was an error. Quite a number of other Catholic and Evangelical Christians share this assumption, but others do not and it does not derive unambiguously from the historical (let alone biblical) evidence.

Gordon Dunstan's own ethical position was also considerably more complicated than Dr Jones suggests. He helped to shape the cautious Anglican support for the legalisation of abortion in the 1960s, but by 1974 he was already expressing considerable reservations: 
The facts of the incidence of induced abortion invite only one conclusion: that abortion is now being widely legalised and practised because that is what people want-an indication for medical intervention for the destruction of life unknown in our ethics before. ${ }^{2}$

By the end of his life he had changed his mind again and spoke from the floor of the Royal Society in October 2000 defending embryonic stem cell research. An important clue about why he regarded such change as justifiable for thoughtful Christians is given in his 1974 account of Anglican bishops in the first half of the 20th century changing their minds about the legitimacy of barrier contraception (still disallowed within official Roman Catholic moral teaching and regarded in earlier Catholic tradition as homicide). Anglican bishops condemned contraception on the grounds that it would "threaten the race" in 1920; recommended "abstinence from intercourse" as the "primary and obvious method of limiting parenthood" in 1930, but conceded that "other methods" might also be used; and then in 1958 argued that in an overpopulated world methods of contraception were to be left to couples to make their own "positive choice before God". For Dunstan, having taken the theological and historical arguments fully into account, what emerged slowly was: a moral judgment already made, tested and acted upon by Christian husbands and wives, episcopal and clerical as well as lay, for years before; they had, despite ecclesiastical discouragement, admitted contraception into their married lives and could not convict themselves of sin in having done so (Dunstan, ${ }^{2} \mathrm{p} 48$ ).

I doubt if Dr Jones would recognise the legitimacy of such a (pastoral) method in Christian ethics, but Gordon Dunstan regarded it as characteristic of Anglicans, and perhaps finally of Aquinas as well. It is just possible that the gradualist position on abortion (articulated principally by John Habgood rather than by Dunstan) has re-emerged repeatedly within Christian tradition precisely because it responds to pastoral experience. For many women (as well for doctors and pastors), it seems that there really is a fundamental difference between the trauma and grief surrounding perinatal death and the disappointment and sometimes deep frustration of an early spontaneous abortion. Indeed it seems that it is quite normal for women to have a sense of the increasing value and importance of fetuses as they develop in the womb: and for many there does seem to be a real qualitative difference between using a coil or pill to prevent implantation and undergoing a late term abortion. The very fact that late term induced abortions in Britain still represent only a tiny proportion of all induced abortions (even though they are slightly rising at the moment) does seem to indicate as much.

In my view, there is also something odd theologically about believing that an embryo has a soul that can survive death from the moment of conception. Since a majority of early embryos abort spontaneously, in terms of this belief it would appear that heaven is mostly populated by them rather than by people who had actually been born. At a less celestial level, it also means that it is not only embryonic stem cell research and induced abortion that must be disallowed, but most forms of IVF as well. In other words "a moral judgment [about IVF] already made, tested and acted upon by Christian husbands and wives" (and, of course, by many other morally sensitive people) must now be judged to be homicide. I find that very difficult to accept.

J Med Ethics 2005;31:713-714. doi: 10.1136/jme.2005.012153

Correspondence to: Professor Robin Gill, University of Theology, University of Kent, Canterbury, CT2 7NF, UK; r.gill@ukc.ac.uk

Received 29 March 2005

Accepted for publication 3 May 2005

\section{REFERENCES}

1 Jones DA. The soul of the embryo: an enquiry into the status of the human embryo in the Christian tradition. London: Continuum, 2004.

2 Dunstan GR. The artifice of ethics. London: SCM Press, 1974:87. 